\title{
The Ag/Au ratio of native gold and electrum and the geochemical environment of gold vein deposits in Japan
}

\author{
N. Shikazono ${ }^{1}$ and M.Shimizu ${ }^{2}$ \\ ${ }^{1}$ Geological Institute, Faculty of Science, University of Tokyo, Tokyo 113, Japan \\ ${ }^{2}$ Department of Petrology and Mineral Deposits, University Museum, University of Tokyo, Tokyo 113, Japan
}

\begin{abstract}
The chemical composition of native gold and electrum from auriferous vein and gold-silver vein deposits in Japan has been analyzed and summarized. The $\mathrm{Ag} / \mathrm{Au}$ ratios of native gold and electrum from these two types of deposits are distinct, i.e., $10-20 \mathrm{Ag}$ at $\%$ (auriferous vein) and $30-70 \mathrm{Ag}$ at $\%$ (gold-silver vein). Thermochemical calculations suggest that the $\mathrm{Ag} / \mathrm{Au}$ ratio of native gold and electrum should decrease with increasing chloride concentration and temperature. This is consistent with analytical results of native gold and electrum and fluid inclusion studies. Based on the Ag content of native gold and electrum, the Fe content of sphalerite, and the estimated temperatures, it is deduced that the sulfur activity for auriferous vein-type systems was lower than that of gold-silver vein-type systems.
\end{abstract}

The two types of gold vein deposits occurring in Japan are "auriferous veins in sedimentary terrain" and "gold-silver veins in volcanic terrain" according to the classification by Boyle $(1979,1984)$. In this paper these deposits are called auriferous vein and gold-silver vein deposits, respectively. There are distinct differences in the characteristics of these two deposit types. For instance, the gold-silver vein deposits occur mainly in Tertiary/Quaternary volcanic regions while the auriferous vein deposits occur in sedimentary terrain associated with Cretaceous felsic plutonic activity or in regionally metamorphosed rocks (Fig. 1). Common opaque minerals from the gold-silver veins are electrum, argenitite, Ag sulfosalts (pyrargyrite, polybasite), sphalerite, pyrite, chalcopyrite, and galena. Native gold, electrum, pyrite, pyrrhotite, chalcopyrite, cubanite, sphalerite, arsenopyrite, and tellurobismutite occur in the auriferous vein deposits. Sulfide minerals are generally abundant in gold-silver veins compared with the auriferous veins. It is noteworthy that silver minerals are abundant in gold-silver veins, whereas they are poor in auriferous veins. $\mathrm{Ag} / \mathrm{Au}$ total production ratio of goldsilver veins is generally greater than 10 (usually $10-20$ ) and that of auriferous veins is less than 10. More detailed information on these deposits is available in Urashima (1974) and Shikazono (1986) for gold-silver vein and Watanabe (1936) and Nedachi (1974) for auriferous vein deposits.

There is a large amount of analytical data available for electrum from Japanese gold-silver vein deposits (e.g.,
Yamaoka and Nedachi 1978; Shikazono 1985 a). Also, the geochemical environment (activity of $\mathrm{O}_{2}$ and $\mathrm{S}_{2}$, i.e., $\mathrm{a}_{\mathrm{O}_{2}}$ and $\mathrm{a}_{\mathrm{S}_{2}}, \mathrm{pH}$, total dissolved sulfur concentration, and temperature) of these deposits has been estimated (Shikazono 1974, 1977 a, 1978; Hattori 1975; Takeuchi and Shikazono 1984). In contrast, few analytical data on native gold and electrum from auriferous vein deposits are available and the geochemical environment has not been elucidated except for the Kohoku deposit (Nedachi 1974).

The objectives of this paper are to (1) present analytical data on native gold and electrum from representative auriferous vein deposits in Japan, (2) compare analytical data on the native gold and electrum from auriferous veins with those from gold-silver veins, and (3) discuss the chemical features of ore fluids responsible for the auriferous vein deposits.

Analytical data on sphalerite coexisting with native gold and electrum is also reported since the chemical composition of this mineral is a very useful indicator of the environment of ore deposition.

In the following sections, Au-Ag alloy containing less than $20 \mathrm{wt} \% \mathrm{Ag}$ is called native gold and $\mathrm{Au}-\mathrm{Ag}$ alloy containing more than $20 \mathrm{wt} \% \mathrm{Ag}$ is called electrum.

\section{Analytical procedure and results}

Chemical analysis of native gold, electrum, and sphalerite from the auriferous vein deposits in Japan was performed with a Jeol 733 electron microprobe analyser at the Ocean Research Institute, University of Tokyo. The accelerating voltage was $25 \mathrm{kV}$, and the standards for analyses were pure gold metal (for $\mathrm{Au}$ ), pure silver metal $(\mathrm{Ag})$, natural chalcopyrite with known composition $(\mathrm{Cu})$, synthetic $\mathrm{Zn}_{0.6}$ $\mathrm{Fe}_{0.4} \mathrm{~S}$ ( $\mathrm{Zn}, \mathrm{Fe}$, and $\mathrm{S}$ ), synthetic $\mathrm{CdS}(\mathrm{Cd})$, synthetic $\mathrm{MnS}$ $(\mathrm{Mn})$, and synthetic $\mathrm{CuInS}_{2}$ (In). The characteristic X-ray intensities for each point were measured twice for a fixed interval of five seconds; the averaged values were corrected for dead time and background. Quantitative corrections were made for atomic number and absorption and fluorescence effects, based on the method of Sweatman and Long (1969).

Locations of the thirteen auriferous vein deposits studied are shown in Fig. 1. Auriferous vein deposits can be divided into two types on the basis of their host rocks, i.e., deposits occurring in sedimentary and volcanic terrains associated with felsic plutonic activity of Cretaceous age 


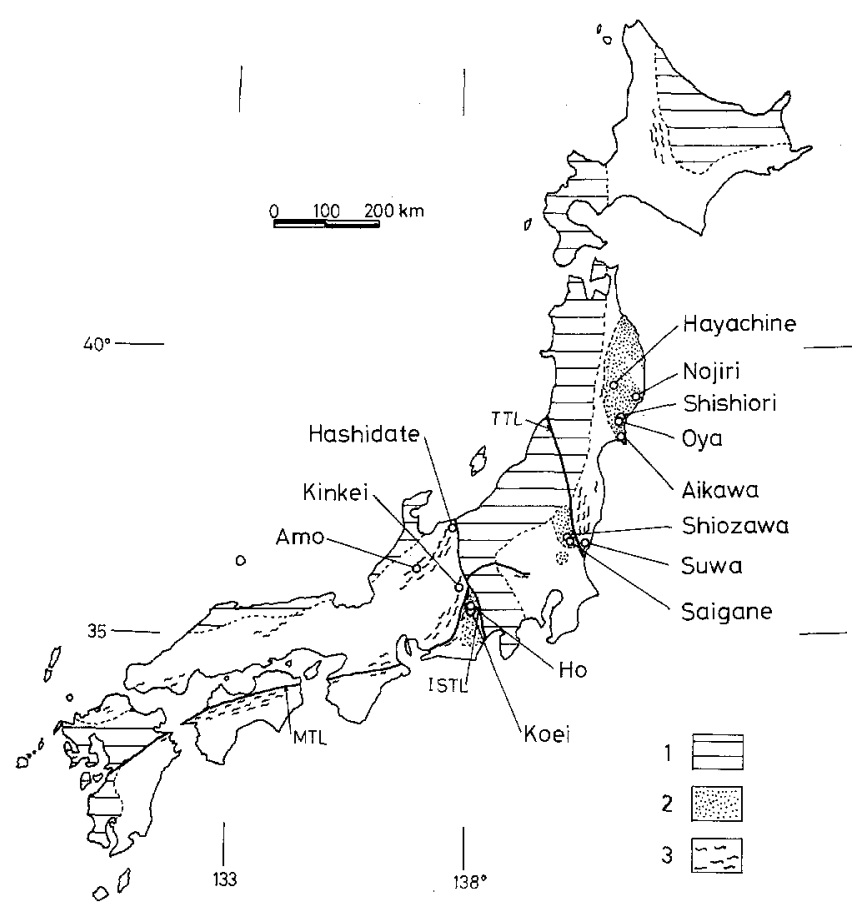

Fig. 1. Map of Japan showing the locations of auriferous vein deposits studied. 1, Green tuff and subaerial volcanic regions of Tertiary/Quaternary age; 2, main Paleozoic/Mesozoic sedimentary terranes; 3, main metamorphic terranes. TTL, Tanakura Tectonic Line; MTL, Median Tectonic Line; ISTL, Itoigawa-Shizuoka Tectonic Line

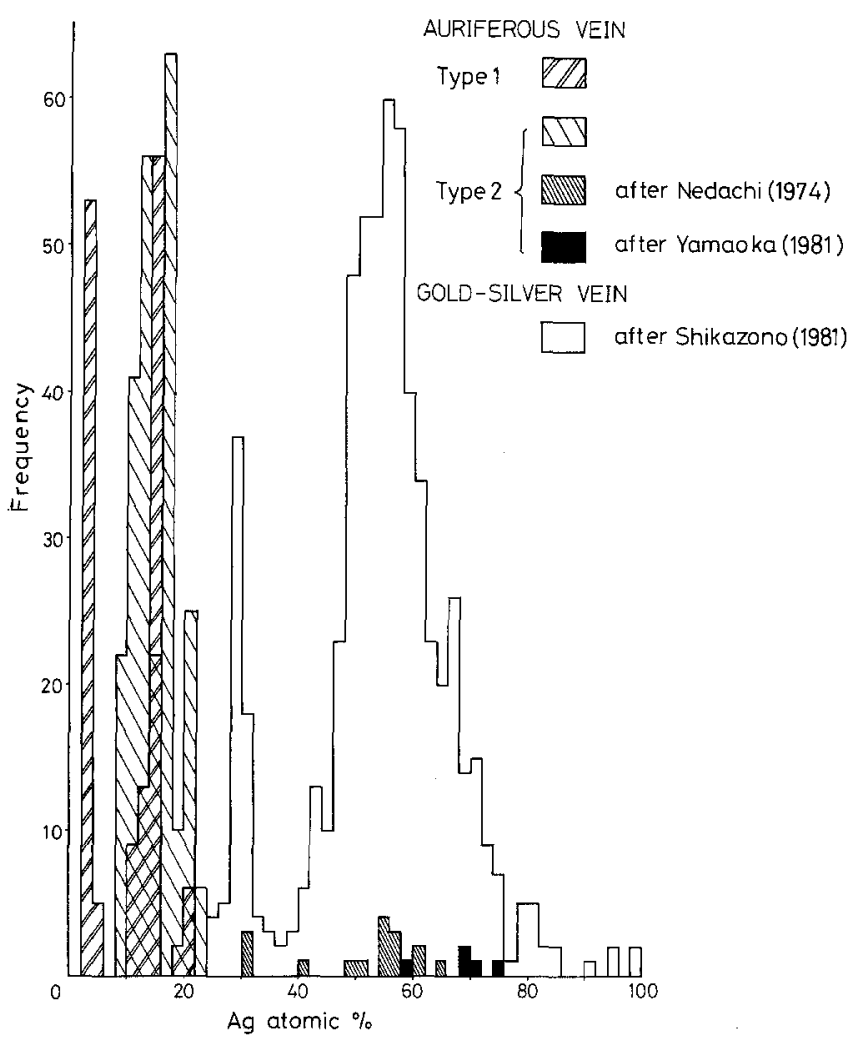

Fig. 2. Frequency (number of analysis) histogram of Ag content (at \%) of auriferous vein and gold-silver vein deposits in Japan. Frequency means numbers of analyses. Data are from the present investigation. Nedachi (1974), Abe (1981), and Yamaoka (1981) for auriferous vein deposits and Shikazono $(1981,1985 \mathrm{a}, 1986)$ for gold-silver vein deposits

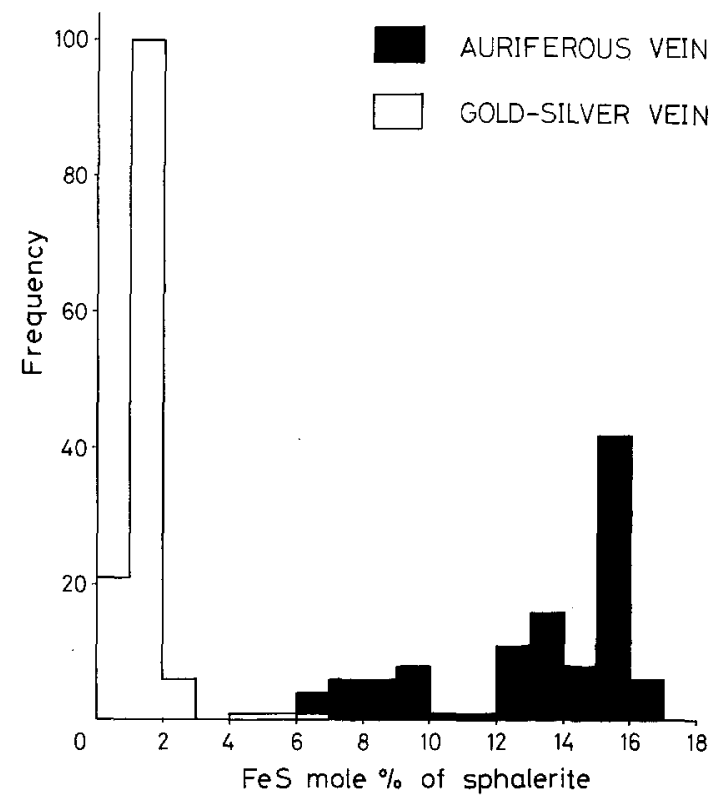

Fig. 3. Frequency (number of analysis) histogram of FeS content (mol \%) of sphalerite from auriferous vein deposits in Japan. Data are from the present investigation and Nedachi (1974), and Yamaoka (1981) for auriferous vein deposits and Shikazono (1974, 1977 b), Sugaki et al. (1982, 1984), Soeda and Watanabe (1981), and Taguchi and Hirowatari (1981) for gold-silver vein deposits

(type 1) and deposits occurring in rocks affected by regional metamorphism (type 2). Gold-silver vein deposits occur in regions of Tertiary/Quaternary volcanic activity.

The $\mathrm{Ag}$ at $\%$ of native gold and electrum is summarized in Fig. 2. Three points are evident (Fig. 2), i.e., (1) the $\mathrm{Ag}$ at $\%$ in native gold and electrum from auriferous vein deposits is low and has a narrow range of 5-20, (2) the $\mathrm{Ag}$ at $\%$ for type- 1 is lower than that for type- 2 auriferous veins, and (3) the composition of native gold and electrum from gold-silver vein deposits ranges $30-70$ at $\% \mathrm{Ag}$, and is clearly higher than for the auriferous vein deposits.

Sphalerite coexisting with native gold and electrum was selected for electron microprobe analysis. The common minerals coexisting with sphalerite are pyrite, pyrrhotite, arsenopyrite, and galena. The ranges of $\mathrm{Fe}, \mathrm{Cd}$, $\mathrm{Mn}$, and In contents of sphalerite are 3.7-9.6, 0.2-1.2, $0.0-0.2$, and $0.0-0.1$, respectively. Frequency histograms of the Fe content of sphalerite coexisting with native gold and electrum from auriferous vein deposits and from goldsilver vein deposits in Japan are summarized in Fig. 3. It is evident that the $\mathrm{Fe}$ content of sphalerite from auriferous vein deposits is higher than that from gold-silver vein deposits.

\section{Factors controlling the Ag/Au ratio of native gold and electrum}

It is essential to know the mode of transport of $\mathrm{Au}$ and $\mathrm{Ag}$ in ore fluids to consider the factors which control the $\mathrm{Ag} / \mathrm{Au}$ ratio of native gold and electrum. Many studies on $\mathrm{Au}$ and $\mathrm{Ag}$ complexes in ore fluids have been conducted 
and reviewed by several workers (Barnes and Czamanske 1967; Barnes 1978; Seward 1981; Shenberger 1986). According to these previous studies, the most dominant dissolved states of $\mathrm{Au}$ and $\mathrm{Ag}$ in ore fluids are bisulfide and chloride complexes, depending on the chemistry of the fluid ( $\mathrm{pH}$, salinity, redox state, etc.). However, experimental studies of Au solubility due to chloride complexes and $\mathrm{Ag}$ solubility due to bisulfide complexes under hydrothermal conditions of interest here have not been published. Unfortunately, the effects of these important species on the $\mathrm{Ag} / \mathrm{Au}$ of native gold and electrum thus cannot be evaluated. Other Au and Ag complexes with tellurium, selenium, bismuth, antimony, and arsenic may be stable in ore fluids but are not taken into account here due to lack of data.

Assuming that $\mathrm{Au}$ is transported dominantly as bisulfide or chloride complexes, the following reaction can be used to determine which species are dominant under near neutral conditions:

$\mathrm{AuCl}_{2}^{-}+2 \mathrm{H}_{2} \mathrm{~S}=\mathrm{Au}(\mathrm{HS})_{2}^{-}+2 \mathrm{Cl}^{-}+2 \mathrm{H}^{+}$.

From the equilibrium relation for Eq. (1) we obtain

$\mathrm{a}_{\mathrm{AuCl}_{2}^{-}} / \mathrm{a}_{\mathrm{Au}(\mathrm{HS})_{2}^{-}}=\mathrm{m}_{\mathrm{AuCl}_{2}^{-}} / \mathrm{m}_{\mathrm{Au}(\mathrm{HS})_{2}^{-}}=\left(\mathrm{a}_{\mathrm{Cl}^{-}}^{2} \cdot \mathrm{a}_{\mathrm{H}^{+}}^{2}\right) /\left(\mathrm{K}_{1} \cdot \mathrm{a}_{\mathrm{H}_{2} \mathrm{~S}}^{2}\right)$,

whereby $a$ is activity, $m$ is molality, and $K_{1}$ is the equilibrium constant for Eq. (1). It is assumed that the activity coefficient ratio, $\gamma_{\mathrm{AuCl}_{2}^{-1}} / \gamma_{\mathrm{Au}(\mathrm{HS})_{2}}$, is one.

Several investigations to elucidate the geochemical environment of Japanese epithermal gold-silver vein-type deposits have been conducted (Shikazono 1974, 1977 a, $1978,1985 \mathrm{a}, \mathrm{b})$. Based on these studies, the values of $\mathrm{m}_{\mathrm{AuCl}_{2}^{-}} / \mathrm{m}_{\mathrm{Au}(\mathrm{HS})_{2}^{-}}$as a function of temperature may be calculated (Fig. 4), by taking the average values for $\mathrm{a}_{\mathrm{Cl}^{-}}$, $\mathrm{a}_{\mathrm{H}^{+}}, \mathrm{a}_{\mathrm{H}_{2} \mathrm{~S}}$, and temperature. The ratio of $\mathrm{m}_{\mathrm{AuCl}_{2}^{-}} / \mathrm{m}_{\mathrm{Au}(\mathrm{HS})_{2}^{-}}$ increases with increasing temperature and $\mathrm{a}_{\mathrm{Cl}^{-}}$(Fig. 4), while an increase in $\mathrm{pH}$ causes a decrease in $\mathrm{m}_{\mathrm{AuCl}^{-}}$$\mathrm{m}_{\mathrm{Au}(\mathrm{HS})_{2}^{-}}$. From Fig. 4 it is apparent that gold bisulfide species are more abundant than gold chloride species under the geochemical conditions common for ore fluids responsible for Japanese gold-silver veins, as already pointed out by several workers (Shikazono 1974; Ichikuni 1981). However, gold chloride species may dominate gold bisulfide species in ore fluids responsible for the auriferous vein deposits, as shown in Fig. 4.

\section{Relationship between the $\mathrm{Ag} / \mathrm{Au}$ ratio of native gold or electrum and physicochemical variables in $\mathrm{AgCl}_{2}^{-}$- and $\mathrm{Au}(\mathrm{HS})_{2}^{-}$-dominant fluids}

Assuming that $\mathrm{AgCl}_{2}^{-}$and $\mathrm{Au}(\mathrm{HS})_{2}^{-}$are the predominant $\mathrm{Ag}$ and $\mathrm{Au}$ species, the following reaction may be used to derive the relationship between the $\mathrm{Ag} / \mathrm{Au}$ ratio of native gold or electrum and temperature or other variables:

$(\mathrm{Au})+\mathrm{AgCl}_{2}^{-}+2 \mathrm{H}_{2} \mathrm{~S}=(\mathrm{Ag})+\mathrm{Au}(\mathrm{HS})_{2}^{-}+2 \mathrm{Cl}^{-}+2 \mathrm{H}^{+}$,

whereby $(\mathrm{Au})$ and $(\mathrm{Ag})$ are the $\mathrm{Au}$ and $\mathrm{Ag}$ components of native gold and electrum, respectively. From the equilibrium relation for $\mathrm{Eq}$. (3) we obtain

$\left.\mathrm{a}_{\mathrm{Ag}} / \mathrm{a}_{\mathrm{Au}}=\left(\mathrm{a}^{2} \mathrm{H}_{2} \mathrm{~S} \cdot \mathrm{m}_{\mathrm{AgCl}_{2}} \cdot \mathrm{K}_{3}\right) / \mathrm{m}_{\mathrm{Au}(\mathrm{HS})_{2}^{-}} \cdot \mathrm{a}_{\mathrm{Cl}^{-}}^{2} \cdot \mathrm{a}_{\mathrm{H}^{+}}^{2}\right)$,

whereby $\mathrm{K}_{3}$ is the equilibrium constant for Eq. (3).

Equation (4) implies that the $a_{A g} / a_{A u}$ of native gold and electrum is controlled by temperature, $\mathrm{a}_{\mathrm{Cl}^{-}}, \mathrm{a}_{\mathrm{H}_{2} \mathrm{~S}}, \mathrm{pH}$, and $\mathrm{m}_{\mathrm{AgCl}_{2}^{-}} / \mathrm{m}_{\mathrm{Au}(\mathrm{HS})_{2}^{-}}$.

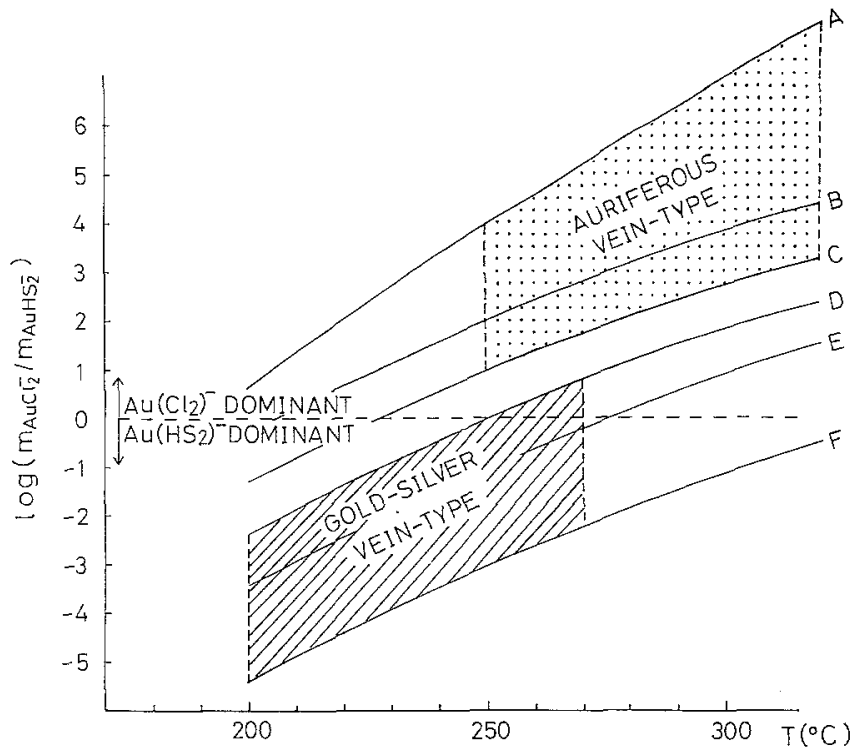

Fig. 4. The relationship between $\mathrm{m}_{\mathrm{AuCl}_{2}^{-}} / \mathrm{m}_{\mathrm{Au}(\mathrm{HS})_{2}^{-}}$and temperature. Hatched and dotted areas represent the probable geochemical environment for typical Japanese gold-silver vein and auriferous vein deposits, respectively. $A, m_{C^{-}}=10, m_{K^{+}}=2, a_{H_{2} S}=10^{-3}$, $\mathrm{K}$-feldspar/K-mica/quartz equilibrium; $\mathrm{B}, \mathrm{m}_{\mathrm{Cl}^{-}}=1, \mathrm{~m}_{\mathrm{K}^{+}}=0.2$, $\mathrm{a}_{\mathrm{H}_{2} \mathrm{~S}}=10^{-3.5}, \mathrm{~K}$-feldspar/K-mica/quartz equilibrium; $\mathrm{C}, \mathrm{m}_{\mathrm{Cl}^{-}}=1$, $\mathrm{m}_{\mathrm{K}^{+}}=0.2, \mathrm{a}_{\mathrm{H}_{2} \mathrm{~s}}=10^{-2}, \mathrm{~K}$-feldspar/K-mica/quartz equilibrium; $\mathrm{D}$, $\mathrm{m}_{\mathrm{Cl}^{-}}=0.2, \quad \mathrm{~m}_{\mathrm{K}^{+}}=0.04, \quad \mathrm{a}_{\mathrm{H}_{2} \mathrm{~s}}=10^{-2}, \quad \mathrm{~K}$-feldspar/K-mica/quartz equilibrium; $\mathrm{E}, \mathrm{m}_{\mathrm{Cl}^{-}}=0.2, \mathrm{~m}_{\mathrm{K}^{+}}=0.04, \mathrm{a}_{\mathrm{H}_{2} \mathrm{~S}}=10^{-3}, \mathrm{~K}$-feldspar/ $\mathrm{K}$-mica/quartz equilibrium; $\mathrm{F}, \mathrm{m}_{\mathrm{Cl}^{-}}=0.2, \mathrm{~m}_{\mathrm{K}^{+}}=0.04, \mathrm{a}_{\mathrm{H}_{2} \mathrm{~S}}=10^{-2}$, $\mathrm{K}$-feldspar/K-mica/quartz equilibrium. Thermochemical data for the calculations were taken from Helgeson (1969), Seward (1973), Drummond (1981), and Henley et al. (1984)

The curves representing the relationship between temperature and $\mathrm{a}_{\mathrm{Ag}} / \mathrm{a}_{\mathrm{Au}}\left(\mathrm{a}_{\mathrm{Ag}}\right.$, activity of $\mathrm{Ag}$ component in native gold or electrum: $a_{A u}$, activity of Au component in native gold or electrum) are shown in Fig. 5. It is assumed that $\mathrm{a}_{\mathrm{K}^{+}} / \mathrm{a}_{\mathrm{H}^{+}}$is controlled by the $\mathrm{K}$-feldspar/K-mica/ quartz assemblage which commonly occurs in gold-silver vein deposits in Japan (Shikazono 1974). The values of $\mathrm{H}_{2} \mathrm{~S}$ activity in ore fluids responsible for gold-silver veins are assumed to be $10^{-2}-10^{-3}$, which are estimated from sulfide mineral assemblage and chemical compositions of minerals (e.g., $\mathrm{Fe}$ content of sphalerite; e.g., Shikazono 1974).

\section{Relationship between the $\mathrm{Ag} / \mathrm{Au}$ ratio of native gold or electrum and physicochemical variables in $\mathrm{AuCl}_{2}^{-}$- and $\mathrm{AgCl}_{2}^{-}$-dominant fluids}

The transport of $\mathrm{Au}$ in the ore fluids responsible for the auriferous veins probably takes place as gold chloride complexes rather than as gold bisulfide complexes (Fig. 2). This suggestion is based on the fact that the temperature of formation of auriferous vein deposits is high (probably $250^{\circ}-350^{\circ} \mathrm{C}$ ) and the chloride concentration of the ore fluids is high (probably more than 1 mole and less than 10 mole) based on the fluid inclusion studies (e.g., Nedachi 1974; Shikazono, unpublished). Based on preliminary experimental data on the solubility of $\mathrm{Au}$ due to chloride complexes (Henley 1973) Au is highly soluble at 


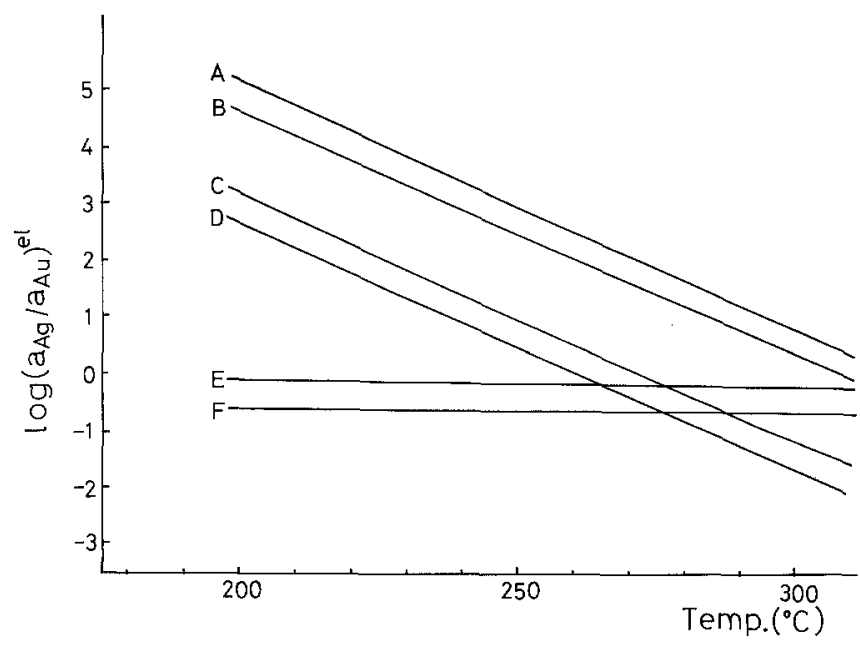

Fig. 5. The relationship between $a_{A g} / a_{A u}$ of native gold and electrum and temperatures. $\mathrm{A}, \mathrm{a}_{\mathrm{H}_{2} \mathrm{~S}}=10^{-2}, \mathrm{~m}_{\mathrm{Cl}^{-}}=0.2, \mathrm{~m}_{\mathrm{K}^{+}}=0.04$, $\mathrm{a}_{\mathrm{AgCl}_{2}^{-}} / \mathrm{a}_{\mathrm{Au}(\mathrm{HS})_{2}}=10^{2.0}, \mathrm{~K}$-feldspar $/ \mathrm{K}$-mica/quartz equlibrium; $\mathrm{B}$, $\mathrm{a}_{\mathrm{H}_{2} \mathrm{~S}}=10^{-2}, \mathrm{~m}_{\mathrm{Cl}^{-}}=0.2, \mathrm{~m}_{\mathrm{K}^{+}}=0.04, \mathrm{a}_{\mathrm{AgCl}_{2}^{-}} / \mathrm{a}_{\mathrm{Au}(\mathrm{HS})_{2}}=10^{1.5} ; \mathrm{C}, \mathrm{a}_{\mathrm{H}_{2} \mathrm{~S}}=10^{-3}$, $\mathrm{m}_{\mathrm{Cl}^{-}}=0.2, \mathrm{~m}_{\mathrm{K}^{+}}=0.04, \mathrm{a}_{\mathrm{AgCl}_{2}} / \mathrm{a}_{\mathrm{Au}(\mathrm{HS})_{2}}=10^{2.0} ; \mathrm{D}, \mathrm{a}_{\mathrm{H}_{2} \mathrm{~S}}=10^{-3}, \mathrm{~m}_{\mathrm{Cl}^{-}}$ $=0.2, \mathrm{~m}_{\mathrm{K}^{+}}=0.04, \mathrm{a}_{\mathrm{AgCl}_{2}^{-}} / \mathrm{a}_{\mathrm{Au}(\mathrm{HS})_{2}^{-}}=10^{1.5} ; \mathrm{E}, \mathrm{a}_{\mathrm{AgCl}_{2}} / \mathrm{a}_{\mathrm{Au}(\mathrm{HS})_{2}^{-}}=10^{2.0}$; $\mathrm{F}, \mathrm{a}_{\mathrm{AgCl}}^{-1} / \mathrm{a}_{\mathrm{Au}(\mathrm{HS})_{2}^{-}}=10^{1.5}$. Calculations were made assuming $\mathrm{K}$-feldspar/K-mica/quartz equilibrium for $\mathrm{A}, \mathrm{B}, \mathrm{C}$, and $\mathrm{D}$. Thermochemical data for the calculations were taken from Helgeson (1969), Seward (1973, 1976), Drummond (1981), and Henley et al. (1984)

high temperatures and/or in fluids of high chloride concentration.

In fluids where precious metal transport is dominated by $\mathrm{AgCl}_{2}^{-}$and $\mathrm{AuCl}_{2}^{-}$, the following reaction may be written to consider the compositional variation of native gold or electrum:

$(\mathrm{Au})+\mathrm{AgCl}_{2}^{-}=(\mathrm{Ag})+\mathrm{AuCl}_{2}^{-}$.

From the equilibrium relation for Eq. (5) we obtain $\mathrm{a}_{\mathrm{Ag}} / \mathrm{a}_{\mathrm{Au}}=\left(\mathrm{a}_{\mathrm{AgCl}} \cdot \mathrm{K}_{5}\right) / \mathrm{a}_{\mathrm{AuCl}_{2}^{-}}$,

whereby $K_{5}$ is the equilibrium constant for Eq. (5).

Curves $E$ and $F$ in Fig. 5 were drawn assuming that the value of $\Sigma \mathrm{Ag} / \Sigma \mathrm{Au}$ ( $\Sigma \mathrm{Ag}$, total dissolved $\mathrm{Ag}$ concentration; $\Sigma \mathrm{Au}$, total dissolved Au concentration) is approximately $10^{2}-10^{1.5}$, which corresponds to the ratio for crustal rocks. These curves indicate that the $\mathrm{a}_{\mathrm{Ag}} / \mathrm{a}_{\mathrm{Au}}$ ratio of native gold or electrum does not change with temperature at a constant $\Sigma \mathrm{Au} / \Sigma \mathrm{Ag}$ ratio. It is noteworthy that the temperature dependency of the $\mathrm{a}_{\mathrm{Ag}} / \mathrm{a}_{\mathrm{Au}}$ ratio of native gold and electrum in $\mathrm{AuCl}_{2}^{-}$-dominant ore fluids is quite different from that in $\mathrm{Au}(\mathrm{HS})_{2}^{-}$-dominant ore fluids (Fig. 5). This difference may account for the range of variation and the $\mathrm{Ag} / \mathrm{Au}$ ratios of native gold and electrum from auriferous vein and gold-silver vein deposits. However, it has to be noted that uncertainties of thermochemical data on gold chloride species might be large.

\section{Relationship between the $\mathrm{Ag} / \mathrm{Au}$ ratio of native gold or electrum and physicochemical variables in $\mathrm{Au}(\mathrm{HS})_{2}^{-}-$ and $\mathrm{Ag}(\mathrm{HS})_{2}$-dominant fluids}

As suggested by Henley et al. (1984) and Brown (1986), it is possible that $\mathrm{Ag}(\mathrm{HS})_{2}^{-}$is dominant in low-salinity and near neutral ore fluids. Under this condition the $\mathrm{Ag} / \mathrm{Au}$ ratios of electrum and native gold are controlled by the following reaction:

$(\mathrm{Au})+\mathrm{Ag}(\mathrm{HS})_{2}^{-}=(\mathrm{Ag})+\mathrm{Au}(\mathrm{HS})_{2}^{-}$.

It is expected from the equilibrium ration for Eq. (7) that the $\mathrm{Ag} / \mathrm{Au}$ ratios of native gold and electrum are controlled by temperature and $\Sigma \mathrm{Ag} / \Sigma \mathrm{Au}$ in ore fluids, though the equilibrium constant for Eq. (6) has not experimentally been determined.

\section{The $\Sigma \mathrm{Au} / \Sigma \mathrm{Ag}$ ratio of ore fluids}

The $\Sigma \mathrm{Au} / \Sigma \mathrm{Ag}$ ratio in ore fluids responsible for goldsilver veins could be calculated from Eq. (4); the temperature of formation is taken from fluid inclusion studies (Enjoji and Takenouchi 1976; Shikazono 1985b) and the electrum-sphalerite-argentite-pyrite assemblage (Shikazono 1985 a). The $\mathrm{NaCl}$ equivalent concentration of ore fluids is approximated from freezing data on inclusion fluids (Enjoji and Takenouchi 1976), though the final melting temperature of fluid inclusion ice is also affected by $\mathrm{CO}_{2}$ concentration in epithermal ore fluids (Hedenquist and Henley 1985). The $\mathrm{pH}$ values are estimated assuming the equilibrium among K-feldspar, K-mica, and quartz which occur commonly in these deposits; this in turn allows a calculation of the activity of $\mathrm{K}^{+}$. The activity of $\mathrm{H}_{2} \mathrm{~S}$ is estimated based on the equation showing the relation between the partial pressure of $\mathrm{H}_{2} \mathrm{~S}$ gas and temperature for active geothermal waters (Giggenbach 1980; Arnorsson 1985). Using the typical values of these variables and $\mathrm{X}_{\mathrm{Ag}}=0.5$, which is a typical value for electrum from goldsilver veins, $\Sigma \mathrm{Au} / \Sigma \mathrm{Ag}$ is calculated to be about $10^{-1}$, which is similar to that of Broadlands' geothermal water (see Table I). The above calculation is based on the assumption that $\mathrm{AgCl}_{2}^{-}$is the predominant $\mathrm{Ag}$ species in ore fluids. However, Brown (1986) and Henley (1985) recently suggested that silver bisulfide complex $\left(\mathrm{Ag}(\mathrm{HS})_{2}^{-}\right)$ could contribute significantly to the transportation of $\mathrm{Ag}$ in low-salinity geothermal waters (e.g., Broadlands, New Zealand). Thus, silver bisulfide complex is also probable as a dominant $\mathrm{Ag}$ species in ore fluids responsible for gold-silver veins in Japan, though the salinity of ore fluids $(0.1-0.3 \mathrm{M})$ is generally higher than that of Broadlands' geothermal water. If gold and silver bisulfide complexes are the dominant gold and silver species in Broadlands' geothermal water and ore fluids responsible for Japanese gold silver veins, the $\mathrm{Ag} / \mathrm{Au}$ ratio of ore fluids responsible for Japanese gold silver vein may be similar to that of Broadlands' geothermal water which is about 0.1 (Table 1).

If $\mathrm{AgCl}_{2}^{-}$and $\mathrm{AuCl}_{2}^{-}$are the predominant $\mathrm{Ag}$ and $\mathrm{Au}$ species, we can calculate $\Sigma \mathrm{Au} / \Sigma \mathrm{Ag}$ in ore fluids by using thermochemical data on gold chloride complexes by Drummond (1981), Helgeson (1969), and thermochemical mixing properties of Au-Ag alloy by White et al. (1957). The ratio of $\mathrm{X}_{\mathrm{Ag}} / \mathrm{X}_{\mathrm{Au}}(\mathrm{X}$, atomic fraction) for native gold or electrum from auriferous vein deposits is taken to be 0.25 . The calculated value of $\mathrm{m}_{\mathrm{AuCl}_{2}} / \mathrm{m}_{\mathrm{AgCl}_{2}^{-}}$bases on thermochemical data on $\mathrm{AuCl}_{2}^{-}$by Drummond (1981) is about $10^{-2}$. Using thermochemical data for gold chloride complexes compiled by Helgeson (1969), we obtain $\mathrm{m}_{\mathrm{AuCl}_{2}^{-}} / \mathrm{m}_{\mathrm{AgCl}_{2}^{-}}$which is very different from the $\mathrm{Au} / \mathrm{Ag}$ 
Table 1. $\Sigma \mathrm{Au} / \Sigma \mathrm{Ag}$ in ore fluids estimated from chemical composition of native gold and electrum in active geothermal waters and in crustal rocks. $\mathrm{X}_{\mathrm{Ag}}=0.2$ for auriferous veins and $\mathrm{X}_{\mathrm{Ag}}=0.5$ for gold-silver veins are assumed. Assumed values include: (1) $200^{\circ} \mathrm{C}$, $\mathrm{a}_{\mathrm{H}_{2} \mathrm{~S}}=10^{-3.5}, \mathrm{~m}_{\mathrm{Cl}^{-}}=0.1, \mathrm{pH}=5.6 ;(2) 250^{\circ} \mathrm{C}, \mathrm{a}_{\mathrm{H}_{2} \mathrm{~S}}=10^{-2}, \mathrm{~m}_{\mathrm{Cl}^{-}}=0.1, \mathrm{pH}=5.4 ;$ (3) $300^{\circ} \mathrm{C}, \mathrm{a}_{\mathrm{H}_{2} \mathrm{~S}}=10^{-1}, \quad \mathrm{~m}_{\mathrm{Cl}^{-}}=0.1, \quad \mathrm{pH}=5.4 ; \quad$ (4) $300^{\circ} \mathrm{C}$; (5) $300^{\circ} \mathrm{C}$

\begin{tabular}{|c|c|c|c|c|}
\hline & & $\begin{array}{l}\mathrm{Au} / \mathrm{Ag} \\
\text { (atomic ratio) }\end{array}$ & $\log (\mathrm{Au} / \mathrm{Ag})$ & References \\
\hline Crustal rocks (average) & & $0.03-0.01$ & $-1.6--2.0$ & Wehdepohl (1978) \\
\hline Seawater & & $0.013-0.004$ & $-1.1--2.2$ & Holland (1978) \\
\hline \multicolumn{5}{|l|}{ Active geothermal water } \\
\hline Broadlands (BR 22) & & 0.10 & -0.99 & Brown (1986) \\
\hline $\begin{array}{l}\text { Imperial Valley } \\
\text { Magmamax } 1\end{array}$ & & 0.11 & -1.00 & Henley et al. (1984) \\
\hline Beppu & & 0.03 & -1.6 & Koga $(1957,1961)$ \\
\hline \multicolumn{5}{|l|}{ Ore fluids } \\
\hline \multirow[t]{3}{*}{ Gold-silver vein } & (1) & 0.09 & -1.0 & $\begin{array}{l}\text { Thermochemical data from Helgeson (1969), } \\
\text { Seward (1973, 1976), Henley et al. (1984) }\end{array}$ \\
\hline & (2) & 0.09 & -1.0 & $\begin{array}{l}\text { Thermochemical data from Helgeson (1969), } \\
\text { Seward }(1973,1976) \text {, Henley et al. (1984) }\end{array}$ \\
\hline & (3) & 0.08 & -1.1 & $\begin{array}{l}\text { Thermochemical data from Helgeson (1969), } \\
\text { Seward }(1973,1976) \text {, Henley et al. (1984) }\end{array}$ \\
\hline \multirow[t]{3}{*}{ Auriferous vein } & (4) & 0.007 & -2.2 & $\begin{array}{l}\text { Thermochemical data from Drummond (1981), } \\
\text { Seward (1976) }\end{array}$ \\
\hline & (5) & $1.48 \times 10^{-7}$ & -6.8 & $\begin{array}{l}\text { Thermochemical data from Helgeson (1969), } \\
\text { Seward (1976) }\end{array}$ \\
\hline & (6) & 0.007 & -2.2 & $\begin{array}{l}\text { Thermochemical data from Drummond (1981), } \\
\text { Seward (1976) }\end{array}$ \\
\hline
\end{tabular}

ratios of crustal rock and active geothermal waters (Broadlands, New Zealand; Imperial Valley Magmamax 1, California; Beppu, Japan), though the Au/Ag values for the Imperial Valley Magmamax 1 and Beppu geothermal waters do not reflect those in the deep fluid.

\section{Sulfur activity $\left(\mathrm{a}_{\mathrm{S}_{2}}\right)$}

Using the Fe content of sphalerite coexisting with pyrite and temperatures estimated from fluid inclusion studies and the chemical compositions of electrum and sphalerite coexisting with argentite and pyrite, the probable $\mathrm{a}_{\mathbf{S}_{2}}$ and temperature ranges for auriferous vein and gold-silver vein deposits are estimated as shown in Fig. 6. These ranges are distinct from each other. At a given temperature the $\mathrm{a}_{\mathbf{S}_{2}}$ for auriferous veins is lower than that for gold-silver veins.

As already discussed, the $\mathrm{Ag} / \mathrm{Au}$ ratios of native gold and electrum might be controlled by several factors such as temperature, $\mathrm{pH}, \mathrm{a}_{\mathrm{S}_{2}}, \mathrm{~m}_{\mathrm{H}_{2} \mathrm{~S}}$, and $\Sigma \mathrm{Ag} / \Sigma \mathrm{Au}$, although these variables are not independent. In this paper the relationship between these variables was derived, and it was shown that the $\mathrm{Ag} / \mathrm{Au}$ value of electrum and native gold is useful in estimating the geochemical variables $\left(\mathrm{a}_{\mathrm{S}_{2}}\right.$, $\Sigma \mathrm{Au} / \Sigma \mathrm{Ag}$, temperature, etc.) of ore fluids responsible for $\mathrm{Au}-\mathrm{Ag}$ deposition. However, in order to consider more rigorously the mode of transport of $\mathrm{Au}$ and $\mathrm{Ag}$ in ore fluids and the causes for the observed compositional variations in native gold and electrum, better estimates of these variables for the ore deposits studied are necessary. In addition, further thermochemical data on gold and silver complexes (e.g., $\mathrm{AuCl}_{2}^{-}, \mathrm{Au}(\mathrm{HS}) \mathrm{Cl}^{-}, \mathrm{Ag}(\mathrm{HS})_{2}^{-}$, etc.) at elevated temperatures are essential.

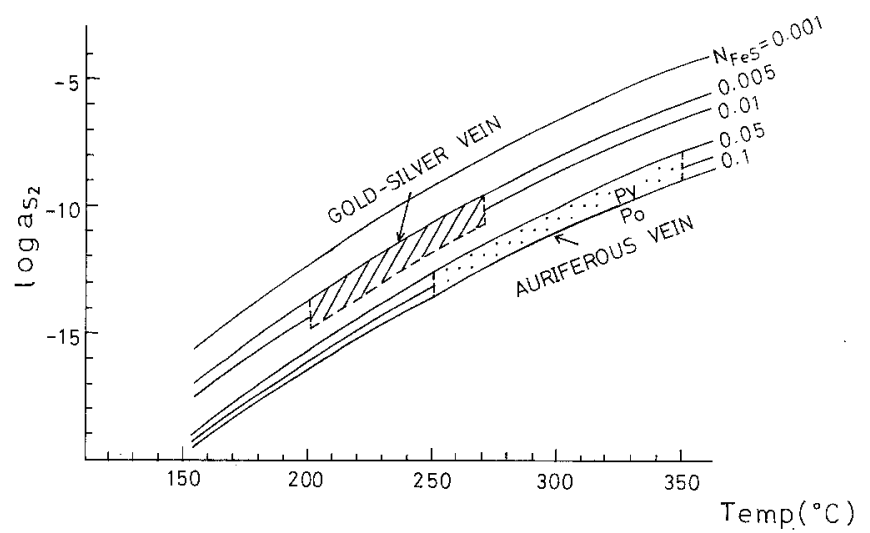

Fig. 6. Typical sulfur activity and temperatur ranges for Japanese auriferous vein (dotted) and gold-silver vein (hatched) deposits. Iso-FeS content curves for sphalerite were drawn based on the equation of Barton and Skinner (1979). py, pyrite; po, pyrrhotite

Acknowledgements. We express our sincere thanks to the staff and graduate students of the Economic Geology Section of the Geological Institute, University of Tokyo, for their valuable comments and discussion. Dr. J. W. Hedenquist reviewed the original manuscript and improved the English. Most samples used for chemical analyses were provided from the collection of the Department of Petrology and Mineral Deposits, University $\mathrm{Mu}$ seum, University of Tokyo. This work was supported in part by funds from the Cooperative Program (No. 85136) provided by the Ocean Research Institute, University of Tokyo, and from a Grant in Aid for Scientific Research No. 60540518 and No. 61740469 from the Ministry of Education of Japan. 


\section{References}

Arnórsson, S.: Gas pressures in geothermal systems. Chem. Geol. $49: 319-328(1985)$

Abe, $\mathrm{H}$.: Chemical compositions of gold ores and $\mathrm{Ag} / \mathrm{Au}$ values of electrums from the Oya mine, Miyagi Prefecture. Mining Geol. Spec. Issue 10:119-125 (1981) (Japanese with English abstract)

Barnes, H.L.: Solubilities of ore minerals. In: Geochemistry of Hydrothermal Ore Deposits, 2nd. ed., H. L. Barnes, Ed., New York; John Wiley and Sons, 404-460 (1978)

Barnes, H.L., Czamanske, G.K.: Solubilities and transport of ore minerals: In: Geochemistry of Hydrothermal Ore Deposits, 1st Ed., H.L. Barnes, Ed., New York; Holt, Rinehart, and Winston, 334-381 (1967)

Barton, P.B., Jr., Skinner, B.J.: Sulfide mineral stabilities. In: Geochemistry of Hydrothermal Ore Deposits, 2nd Ed., H.L. Barnes, Ed., 278-403 New York; John Wiley and Sons, 278403 (1979)

Boyle, R.W. The geochemistry of gold and its deposits. Geol. Surv. Can. Bull. 280, 584 p (1979)

Boyle, R.W.: Gold deposits: Their geology, geochemistry and origin. In: Gold 82. R.P. Foster, Ed., 183-190, A.A. Balcema (1984)

Brown, K.L.: Gold deposition from geothermal discharges in New Zealand. Econ. Geol. 81:979-986 (1986)

Drummond, S.E.: Boiling and Mixing of Hydrothermal Fluids: Chemical Effects on Mineral Precipitation. Unpub. Ph. D. thesis, the Pennsylvania State Univ. 397 p (1981)

Enjoji, M., Takenouchi, S.: Present and future researches of fluid inclusions from vein-type deposits. In: Genesis of Vein-Type Deposits in Japan. T. Nakamura, Ed., Mining Geologists Japan Spec. Issue 7, 85-100 (1976) (Japanese with English abstract)

Giggenbach, W.F.: Geothermal-gas equilibria. Geochim. Cosmochim. Acta. 44:2021-2032 (1980)

Hattori, K.: Geochemistry of ore deposition at the Yatani leadzinc and gold-silver deposits, Japan. Econ. Geol. 70:677-693 (1975)

Hedenquist, J.W., Henley R.W.: Effect of $\mathrm{CO}_{2}$ on freezing-point depression measurements of fluid inclusions for epithermal ore deposition. Econ. Geol. 80:1379-1406 (1985)

Helgeson, H.C.: Thermodynamics of hydrothermal systems at elevated temperatures and pressures. Am. J. Sci. 267:729-804 (1969)

Henley, R.W.: Solubility of gold in hydrothermal chloride solutions. Chem. Geol. 11:73-87 (1973)

Henley, R.W.: The geothermal framework of epithermal deposits. In Reviews in Econ. Geol. v. 2: 1-24 (1985)

Henley, R.W., Truesdell, A.H., Barton, P.B. Jr.: Reviews in Econ. Geol. v. 1:115-127 (1984)

Holland, H.D. : The Chemistry of the Atmosphere and Oceans. New York, Chichester, Brisbane and Toronto; John Wiley and Sons (1978)

Ichikuni, M.: Dissolved state of gold and silver in ore solutions. Mining Geol. Spec. Issue 10:269-273 (1981) (Japanese)

Koga, A.: Silver in Beppu thermal springs. J. Chem. Soc. Japan 78:1717-1721 (1957) (Japanese with English abstract)

Koga, A.: Gold in Beppu thermal springs. J. Chem. Soc. Japan 82: 1476-1478 (1961) (Japanese with English abstract)

Nedachi, M.: Mineralization of the Kohoku gold, silver and copper ore deposits, Miyagi Prefecture, Japan. Sci. Rept. Tohoku Univ. Ser. III, 12:331-394 (1974)

Seward, T.M.: Thio complexes of gold and the transport of gold in hydrothermal ore solutions. Geochim. Cosmochim. Acta 37: 379-399 (1973)

Seward, T.M.: The stability of chloride complexes of silver in hydrothermal solutions up to $350^{\circ} \mathrm{C}$. Geochim. Cosmochim. Acta 40: 1329-1341 (1976)

Seward, T.M.: Metal complex formation in aqueous solutions at elevated temperatures and pressures. In: Chemistry and Geo- chemistry of Solutions at High Temperatures and Pressures, D.T. Rickard, F.E. Wickman, Ed., Phys. Chem. Earth 13 and 14: 113-132 (1981)

Shenberger, D.M.: Gold solubility in aqueous sulfide solutions. Unpub. Master thesis, Pennsylvania State Univ. (1986)

Shikazono, N.: Physicochemical environment and mechanism of volcanic hydrothermal ore deposition in Japan, with special reference to oxygen fugacity. J. Fac. Sci., Univ. Tokyo 19: 27-56 (1974)

Shikazono, N.: Composition of siderite and the environments of formation of vein-type deposits in Japan. Econ. Geol. 72: 632-641 (1977 a)

Shikazono, N.: Vein-type deposits. In: Fundamental Aspects of the Study of Deposits, Tatsumi, T., Ed., Todai Shuppan Kai (University of Tokyo Press), 188-202 (1977 b) (Japanese)

Shikazono, N.: Selenium content of acanthite and the chemical environments of Japanese vein-type deposits. Econ. Geol. 73:524-533 (1978)

Shikazono, N.: Chemical composition of electrum from the epithermal $\mathrm{Au}-\mathrm{Ag}$ vein-type and Kuroko-type deposits in Japan and its controlling factors. Mining Geol. Spec. Issue 10:259-267 (1981) (Japanese with English abstract)

Shikazono, N.: A comparison of temperatures estimated from the electrum-sphalerite-pyrite-argentite assemblage and filling temperatures of fluid inclusions from epithermal $\mathrm{Au}-\mathrm{Ag}$ veintype deposits in Japan. Econ. Geol. 80: 1415-1424 (1985a)

Shikazono, N.: Gangue minerals from Neogene vein-type deposits in Japan and an estimate of their $\mathrm{CO}_{2}$ fugacity. Econ. Geol. 80:754-768 (1985b)

Shikazono, N.: Ag/Au total production ratio and $\mathrm{Au}-\mathrm{Ag}$ minerals from vein-type and disseminated-type deposits in Japan. Mining Geol. 36:411-424 (1986)

Soeda, A., Watanabe, M.: Electrum-silver tellurides ores of the Takeno mine, Hyogo prefecture, SW Japan, and their genetic significance. Mining Geol. Spec. Issue No. 10:43-52 (1981)

Sugaki, A., Isobe, K., Kitakaze, A.: Silver minerals from the Sanru mine. J. Jpn. Min. Petr. Econ. Geol. 77:65-77 (1982) (Japanese with English abstract)

Sugaki, A., Kitakaze, A., Isobe, K. On the gold-silver deposits of the Koryu mine, Hokkaido, Japan. J. Jpn. Min. Petr. Econ. Geol. 79:405-423 (1984) (Japanese with English abstract)

Sweatman, T.P., Long, J.V.P.: Quantitative electron probe microanalysis of rock-forming minerals. J. Petrol. 10:332-379 (1969)

Taguchi, Y., Hirowatari, F.: Chemical composition of sphalerite associated with gold mineralization at the Fuke mine, Kagoshima prefecture. Mining Geol. Spec. Issue No. 10, 35-42 (1981) (Japanese with English abstract)

Takeuchi, K., Shikazono, N.: Mineralization of the Arakawa No. 4 vein of the Kushikino mine, Kagoshima Prefecture, Japan. Mining Geol. 34: 187-195 (1984)

Urashima, Y.: Gold-silver deposits in Japan. In: Gold and Silver Ore in Japan. Mining and Metallurgical Institute of Japan, Ed., 1-42 (1974) (Japanese)

Watanabe, M.: Gold ore and gold ore deposit. Seibunshashinkosha (1936) (Japanese)

Wedepohl, K.H. (ed.): Handbook of Geochemistry. II-5, Berlin, Heidelberg and New York; Springer-Verlag (1978)

White, J.L., Ore, R.L., Hultgren, R.: The thermodynamic properties of silver-gold alloys. Acta. Metal. 5:747-760 (1957)

Yamaoka, K.: Native gold from Omine (Nippo), Oya, and Owashi mines - On the composition of gold from the contact-metasomatic and the fissure-filling ore deposits in the Kitakami mountains. Mining Geol. Spec. Issue 10: 151-158 (1981) (Japanese with English abstract)

Yamaoka, K., Nedachi, M.: Gold and silver minerals from Chitose and Takatama epithermal deposits. In Gold and Silver ore in Japan: Japan Mining Metall. Inst. Ed., 75-100 (1978) (Japanese)

Received: July 10, 1986

Accepted: May 12, 1987 